\title{
A PILOT RB-SR DATING OF THE SUOMUSJÄRVI ULTRAMYLONITE: EVIDENCE FOR MAJOR POST-SVECOFENNIAN DEFORMATION IN SW FINLAND
}

\author{
MAARTEN PLOEGSMA
}

\begin{abstract}
PLOEGSMA, MAARTEN: A pilot Rb-Sr dating of the Suomusjärvi ultramylonite: evidence for major post-Svecofennian deformation in SW Finland. Bull. Geol. Soc. Finland 63, Part 1, 3-13.

The Suomusjärvi shear zone in the West Uusimaa area in the Proterozoic Svecofennides of SW Finland belongs to a group of late, post-peak metamorphic structures comprising vertical shear zones and folds with vertical fold axes. Fieldand microscopical evidence suggest that these structures can be correlated with a shear zone cutting the Bodom granite with a known U-Pb zircon age of $1641 \pm$ $13 \mathrm{Ma}$. This paper presents the results of a pilot $\mathrm{Rb}$-Sr whole-rock and biotite dating of the Suomusjärvi shear zone. The shear zone cuts the Suomusjärvi tonalite and is locally developed as a 5 meter thick ultramylonite in which the biotite is completely recrystallized. A sample of undeformed tonalite yields a $\mathrm{Rb}-\mathrm{Sr}$ biotite age of $1644 \pm 16 \mathrm{Ma}$, the ultramylonite a biotite age of $1533 \pm 23 \mathrm{Ma}$. The tonalite age is interpreted as a cooling age, while the ultramylonite age represents resetting due to the mylonitization process (deformation, recrystallization and fluid flow) below the biotite $\mathrm{Rb}-\mathrm{Sr}$ blocking temperature of $300-350^{\circ} \mathrm{C}$. The whole-rock data give a meaningless age of $1760 \pm 108 \mathrm{Ma}$, which is the result of partial whole-rock resetting at the scale of the ultramylonitic banding.

It is concluded that the results of the pilot-dating are compatible with the expectations based on other data. This indicates that this group of late deformation structures in the studied area is the result of an important post-Svecofennian event which was previously hardly recognized in south Finland. Structural, isotopical, petrological and fluid inclusion data on the cooling history of the West Uusimaa area are internally consistent, but conflicting with other evidence from southern Finland.
\end{abstract}

Key words: absolute age, $\mathrm{Rb} / \mathrm{Sr}$, ultramylonite, tonalite, shear zones, deformation, Proterozoic, Suomusjärvi, Finland.

Maarten Ploegsma: Instituut voor Aardwetenschappen, Vrije Universiteit, De Boelelaan 1085, 1081 HV Amsterdam, Nederland. Present address: Duitslag 11, 3991 RJ Houten, Nederland.

\section{Introduction: resetting of isotope systems}

Resetting of $\mathrm{Rb}-\mathrm{Sr}$ isotope systems in shear zones is the subject of several studies (e.g., Abbot 1972, Etheridge and Cooper 1981, Hickman and Glassley 1984, Black 1988, Majoor 1988).
Generally, whole-rock data from mylonites yield ages different from their country rock, which is usually ascribed to fluid flow through the shear zone at the time of deformation. Meaningless mixing ages are often the result due to incomplete rehomogenization of the isotope system. Apart 
from the actual age of the deformation event, important issues are the scale and extent on which resetting of the isotope system took place and the composition of the fluid. Using the so-called thinslab dating method (thin slices parallel to the mylonitic layering) for whole-rock dating, it was concluded that $\mathrm{Rb}-\mathrm{Sr}$ isotope resetting can take place at the centimeter (Black 1988), decimeter (Claesson 1980) or meter scale (Abbot 1972, Black et al 1979). It is rarely possible to put welldefined constraints on the composition of the fluid phase.

The present work is a pilot study attempting to date the Suomusjärvi shear zone in SW Finland using $\mathrm{Rb}-\mathrm{Sr}$ biotite and whole-rock dating.

The main reason for this study was field evidence (see below) which indicated that the Suomusjärvi shear zone belongs to a group of structures which is (much) younger than the main regional deformation. This particular sample was chosen because it was taken from an ultramylonite, giving the best chance for complete resetting of the Rb-Sr system during the later event.

\section{Geological setting}

The studied ultramylonite is situated in the West Uusimaa area in the South Svecofennian metamorphic belt (fig 1), which is part of the Early Proterozoic Svecofennides in SW Finland (Simonen 1980, Gaál 1982, Gaál and Gorbatchev 1987). The belt consists of strongly deformed volcano-sedimentary rocks intruded by early- to late-Svecofennian plutonics (Gaál and Gorbatschev 1987) and is bounded by large late Svecofennian granitoid bodies, related to migmatization. The pretectonic intrusives comprise a suite of infracrustal rocks of mainly gabbroic to tonalitic composition, which Colley and Westra (1987) suggest are comagmatic with the volcanics they intrude. The late Svecofennian S-type (Huhma 1986) intrusives occur as large microcline granite masses surrounding and outlining the volcanic belt as well as smaller bodies within the belt. Rapakivi granites, usually termed anorogenic, occur in southern Finland as four large batholiths accompanied by several smaller massifs (Nurmi and Haapala 1986). The Svecofennian belts mainly show amphibolite facies metamorphism. Locally, however, granulite facies conditions are reached, such as in the West Uusimaa Granulite Complex (Parras 1958, Westra and Schreurs 1985, Schreurs 1985).

The regional deformation was studied by Tuominen (1957) and more recently by Schreurs and Westra (1986), Bleeker and Westra (1987), Ploegsma and Westra (1990) and Ploegsma (1989). Three major deformation phases can be recognized (see Fig. 1 for major fold traces): 1) $D_{1}$ caused subhorizontal folding, possibly related to thrust tectonics, and was responsible for the penetrative foliation found throughout the West Uusimaa area. 2) $\mathrm{D}_{2}$, the main phase, was essentialy crustal shortening contemporaneous with the peak of metamorphism. $\mathrm{B}_{2}$ fold axes are subhorizontal, an $\mathrm{S}_{2}$ axial plane foliation is rarely developed. All earlier planar structures were rotated to the subvertical and parallel to the $\mathrm{S}_{2}$ plane. 3) $\mathrm{D}_{3}$ structures consist of NWSE to NE-SW trending folds and shear zones, mainly along the western rim of the West Uusimaa area. Dynamic recrystallization microstructures are characteristic for $\mathrm{D}_{3}$ : e.g. subgrains and recrystallization in and at the rims of deformed quartz grains and oblique foliations of new quartz grains in ribbon structures. Newly formed chlorite, epidote and/or andalusite ( $\mathrm{T}$. Hartel, unpublished results) in metapelites deformed by $\mathrm{D}_{3}$ are evidence of retrogradation, indicating that $\mathrm{D}_{3}$ took place after the metamorphic peak. Several shear zones (e.g. the Suomusjärvi and Johannislund shear zones (Fig. 1) show a subvertical sense of shear indicating east block-up movement (Ploegsma 1987, 1989). B $_{3}$ fold axes are subvertical. Pseudotachylytes (fault/ injection veins resulting from friction melts caused by seismic failure (Sibson 1975)) are related to the shear zones. The pseudotachylytes exhibit crosscutting relationships (Van den Kerk- 


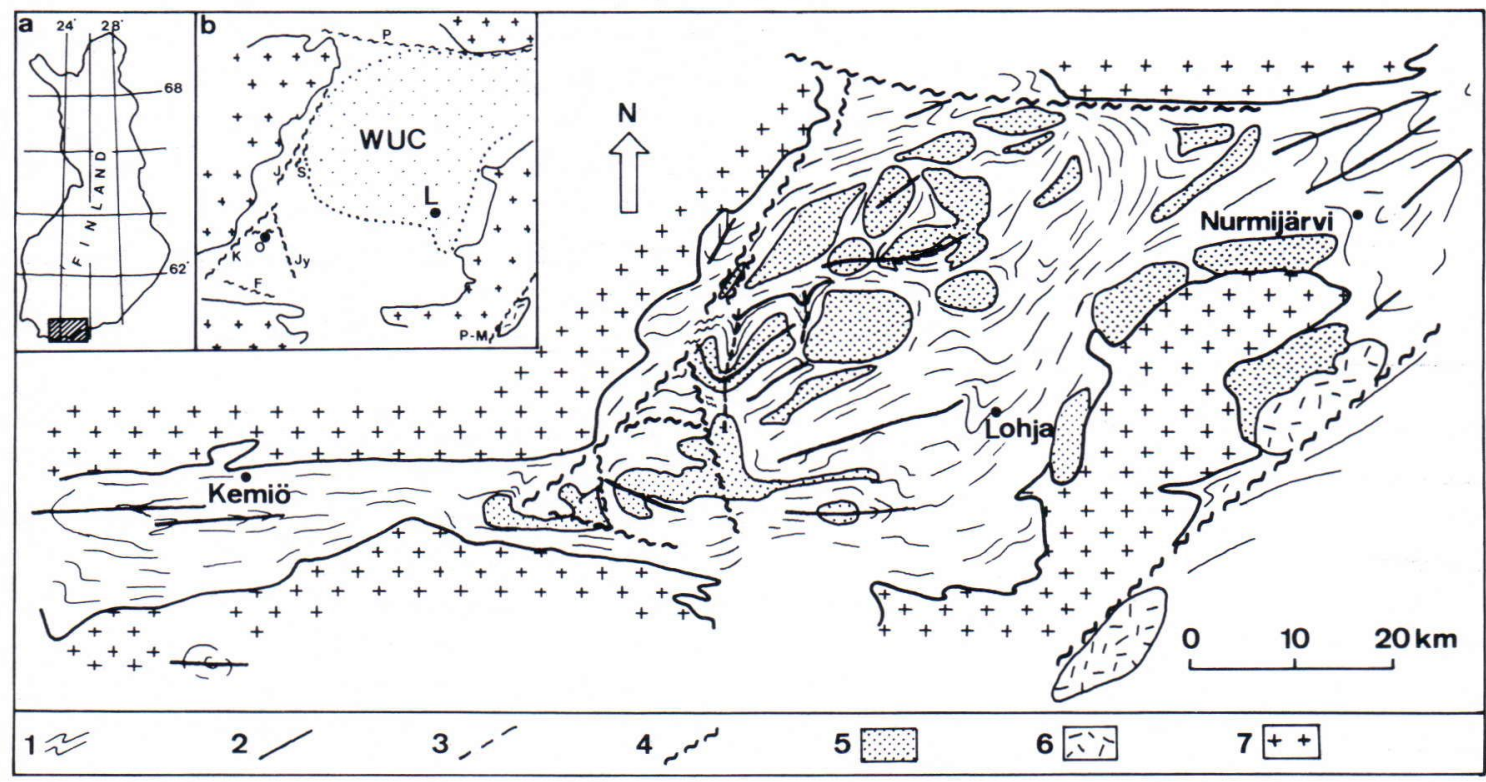

Fig. 1. Schematic structural map of the West Uusimaa area. Symbols. 1. trend of transposed $\mathrm{S}_{0} / / \mathrm{S}_{1}, 2$. axial plane trend of known or inferred major $F_{2}$ fold, 3. axial plane trend of known or inferred major $F_{3}$ fold, 4. late shear zone, 5. granitoid massif, 6. rapakivi granite, 7. late Svecofennian microcline granite. Inset a: location of map area, inset b: metamorphic map and names of shear zones. Dotted area (WUC): West Uusimaa Granulite Complex, white area: amphibolite facies domain. Shear zones: K: Kisko sz; O: Orijärvi sz (black dot is Orijärvi township); Jy: Jyly sz; J: Johannislund sz; F: Fiskars sz; P-M: Porkkala-Mäntsälä sz; P: Painio lineament. From Ploegsma and Westra (1990), with permission of Elseviers Science Publishers.

hof 1984) with ductile $\mathrm{D}_{3}$ mylonitic structures as well as contemporaneous (ductile behaviour in felsic rocks, brittle failure in intermediate to basic rocks, Ploegsma 1989).

The main events in the Svecofennian rocks are well dated: $\mathrm{U}-\mathrm{Pb}$ zircon ages of the volcanic rocks range from 1920-1880 Ma (Simonen 1980), while the synkinematic granitoids were formed mainly 1890 - $1870 \mathrm{Ma}$ ago, late kinematic 1850 $-1800 \mathrm{Ma}$, and postkinematic around $1800 \mathrm{Ma}$ (Nurmi and Haapala 1986). Huhma (1986) dated the early kinematic Orijärvi granodiorite at $1891 \pm 13 \mathrm{Ma}$ (U-Pb zircon age) and the late kinematic Hanko granite at $1830 \pm 10 \mathrm{Ma}(\mathrm{U}-\mathrm{Pb}$ monazite and zircon age). U-Pb ages of rapakivi granites in south Finland range from 17001540 Ma (Vaasjoki 1977).

\section{Scope: an attempt to date the $D_{3}$ deformation}

Two lines of evidence indicate that $\mathrm{D}_{3}$, having caused a hardly recognized but important set of deformation structures, postdated the main Svecofennian events. Firstly, according to Hopgood et al (1983) all major deformations in southern Finland took place in the relatively short timespan of $1900-1885 \mathrm{Ma}$ ago, while the whole Svecofennian orogenic cycle up to initiation of uplift lasted at least $100 \mathrm{Ma}$. This was based on $\mathrm{U}-\mathrm{Pb}$ mineral and $\mathrm{Rb}-\mathrm{Sr}$ whole-rock and mineral data from neosomes cutting folds of various generations, However, the microstructures and geometry of $\mathrm{D}_{3}$ structures as well as the associated retrogression (Ploegsma 1989) suggest that $D_{3}$ postdated the main Svecofennian 
events. Secondly, the Porkkala-Mäntsälä shear zone (P-M, see Fig 1) is a shear zone which is similar in microstructures, stretching direction and strike to $\mathrm{D}_{3}$ shear zones along the western rim of the West Uusimaa area (Ploegsma 1989). The P-M cuts the Bodom and Obbnäs granites near Espoo (Sederholm 1913, Vaasjoki 1977)). Both plutons are considered to be satellite intrusions of the Viborg rapakivi massif (Vaasjoki 1977, Törnroos 1984). Vaasjoki (1977) found a $\mathrm{U}-\mathrm{Pb}$ zircon age of $1641 \pm 13 \mathrm{Ma}$ for the Bodom granite, which is probably the maximum age for $\mathrm{D}_{3}$.

To test the hypothesis of a post-Svecofennian age of $\mathrm{D}_{3}$, a pilot $\mathrm{Rb}-\mathrm{Sr}$ biotite and whole-rock dating was conducted on a sample from the Suomusjärvi ultramylonite and a biotite dating on a sample of (at that location) virtually undeformed Suomusjärvi tonalite. The ultramylonite was chosen for this age determination because all biotite in the rock recrystallized during the deformation process (see below). Totally recrystallized mica's have been shown to yield completely reset $\mathrm{Rb}-\mathrm{Sr}$ ages (Etheridge and Cooper 1981, Majoor 1988). The tonalite biotite was used to test whether a difference exists in isotopic age between undeformed and $\mathrm{D}_{3}$-recrystallized biotite. A thin slice method, similar to the one used by e.g. Etheridge and Cooper (1981) and Krishna Sinha et al (1986), was chosen for the wholerock dating of the ultramylonite, to get more insight in the scale of rehomogenization. A more thorough treatment of the chemical variation between the slices and a comparison with more Suomusjärvi tonalite samples is beyond the scope of this paper, but can be found in Ploegsma (1989), as well as a discussion of the role of fluids, the deformation conditions and the origin of the ultramylonite.

\section{The Suomusjärvi tonalite: sample descriptions}

The Suomusjärvi tonalite (Fig. 2) is one of the numerous elongate tonalite bodies in the West
Uusimaa area. It is located just at the opx-in isograd (Schreurs 1985) and has a mineral assemblage of $\mathrm{q}+$ plag $+\mathrm{bi} \pm \mathrm{cpx}$ (grainsize 1 to $5 \mathrm{~mm}$ ), with in the northern part hypersthene porphyroblasts. Some retrogression to chlorite and/or epidote occurs in samples showing extensive $\mathrm{D}_{3}$ deformation. The tonalite is cut on the western side by the Johannislund shear zone and on the eastern side by the Suomusjärvi shear zone (Fig. 2). The latter is traceable only along the tonalite, while the former runs over a distance of about $40 \mathrm{~km}$ along the western rim of the West Uusimaa area (Fig. 1). In the central parts the tonalite is not or only weakly deformed by $\mathrm{D}_{3}$, but towards the northern and southern parts it exhibits (proto)mylonitic structures characterized by an overall grain size reduction and recrystallization and by polycrystalline quartz ribbons wrapped around plagioclase porphyroclasts. The paragenesis of recrystallized minerals of the mylonites is similar to that of the tonalite itself but orthopyroxene is partially or totally transformed to biotite \pm green amphibole. The contact of the tonalite with the Suomusjärvi shear zone is locally very sharp (Figs. 3 and 4): at the sample locality almost undeformed tonalite is in contact with a c. 5 meter thick ultramylonite. At this contact the ultramylonite banding cuts straight through individual quartz, feldspar and biotite grains which show only minor deformation or recrystallization.

\section{Sample descriptions}

The samples were taken along the E3 section (Fig. 2) through the Suomusjärvi tonalite.

Location $17.1 \mathrm{~K}$ : The ultramylonite is black with light porphyroclasts and the grain size of the matrix is about $5 \mu \mathrm{m}$ (De Ruig en Knap, unpublished data), while the size of the clasts varies from tens of microns to $10 \mathrm{~cm}$. The proportion of clasts is from less than $10 \%$ up to $50 \%$. The rock therefore ranges between heteroclastic mylonite and heteroclastic ultramylonite in the terminology recently proposed by Hanmer (1987). 
Fig. 2. Schematic map of the Suomusjärvi tonalite. 1. sample localities (1: ultramylonite $17.1 \mathrm{~K}, 2$ : tonalite 27.2 ); 2. strike of subvertical mylonitic foliation; 3. azimuth and plunge of extension lineation; $4 . \mathrm{D}_{3}$ shear zone (JSZ: Johannislund shear zone, SSZ Suomusjärvi shear zone); 5. road. u,d: upthrown and downthrown faultblocks.
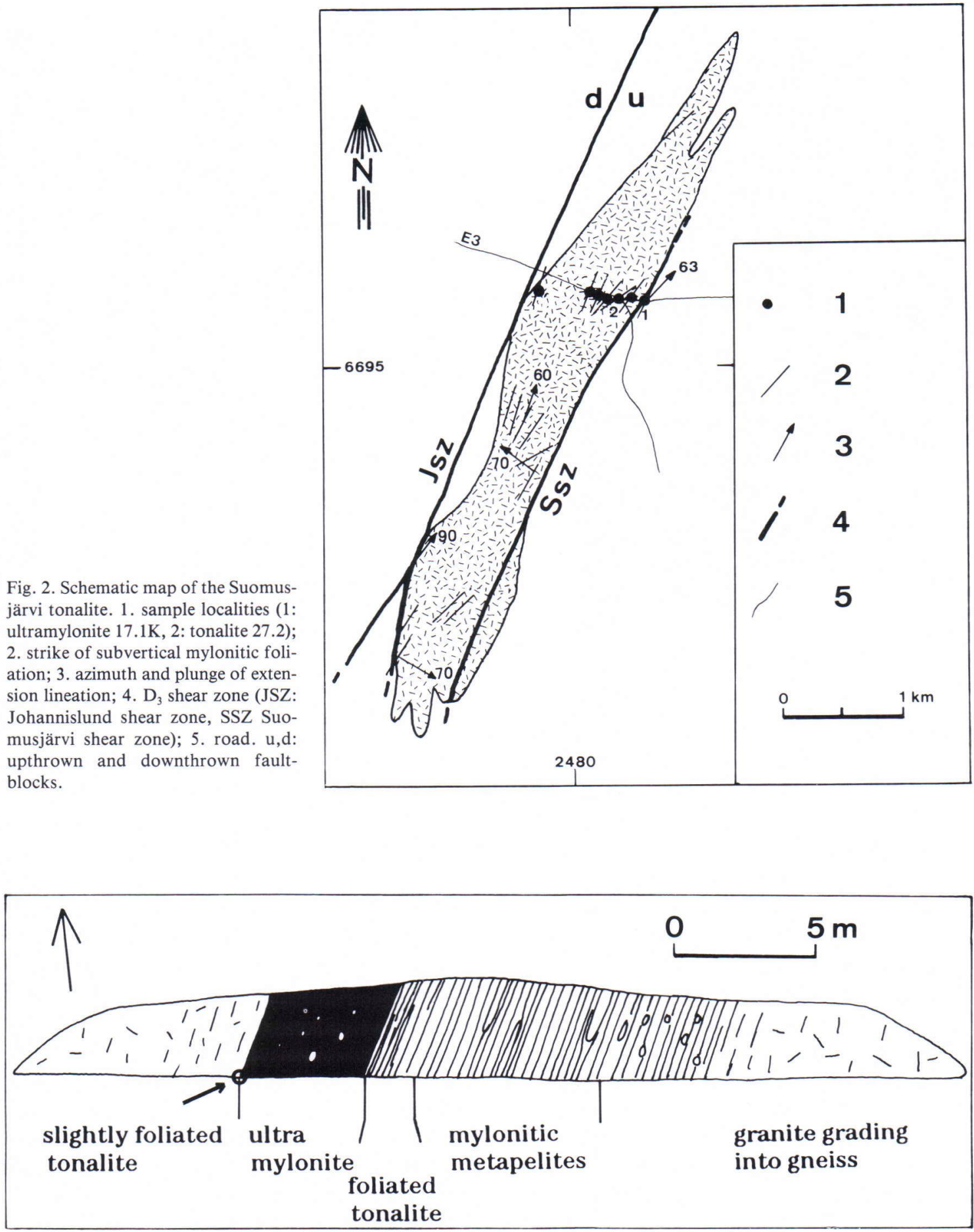

Fig. 3. Field sketch of the contact tonalite-ultramylonite. Note that it is a map view, looking on an ice-polished surface. The sample locality of $17.1 \mathrm{~K}$ is indicated by the arrow. 


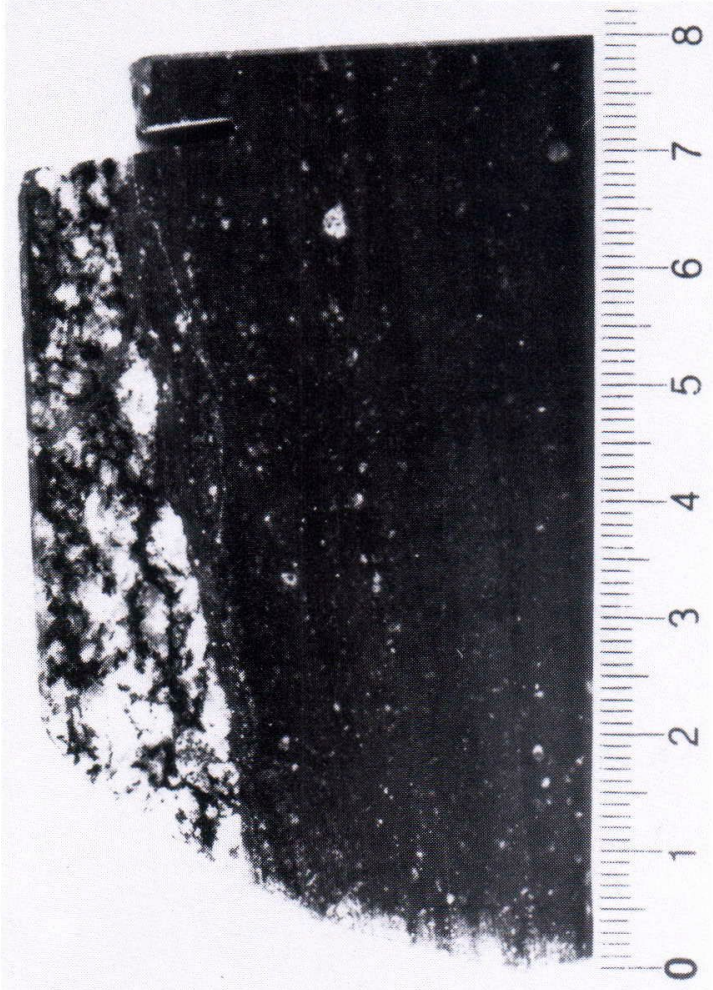

Fig. 4. a: Sample of the contact tonalite-ultramylonite (loc. 17.K1) b: Method of slicing of the ultramylonite. The analysed part is shaded, the stippled area is a biotite-poor band. Slice no. 3 was lost during sample preparation.

In thin section or on a smooth surface (Fig. 4a) the ultramylonite shows a color banding on millimeter scale, due to differences in dark/light mineral ratio. The clasts consist mainly of plagioclase and quartz, often with a mantle of veryfine-grained K-feldspar and tails of plagioclase, quartz and some K-feldspar. Loc. 27.2: Minerals: Q, bi, plag, clinopyroxene retrogaded to cummingtonite and chlorite. Deformation: A faint foliation is formed by biotite aggregates and a shape fabric of plagioclase porphyroblasts and quartz grains. The quartz shows deformation bands which in most cases are parallel to the foliation. The band boundaries are always parallel to the c-axis. Little recrystallization of quartz, plagioclase and biotite occured.

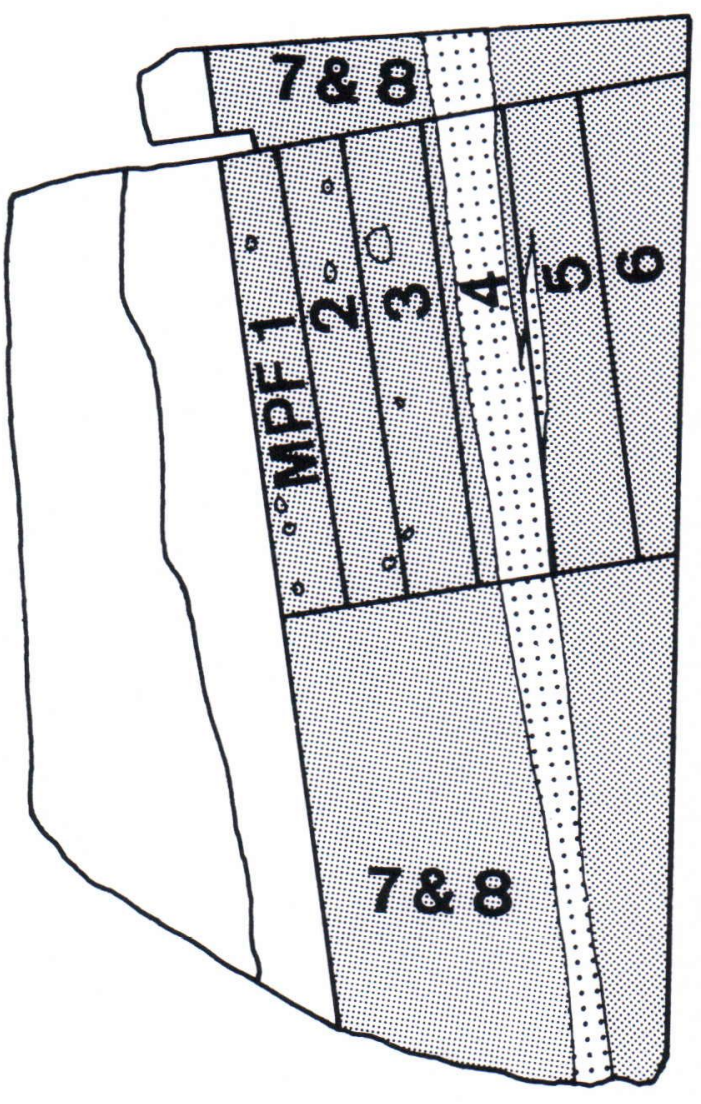

\section{Analytical procedure}

Six slices were cut parallel to the banding for whole-rock dating from a hand specimen (Loc. $17.1 \mathrm{~K})$ of the contact tonalite-ultramylonite (coded no. 1-6 see Fig. 4a and b). A larger part of the ultramylonite sample was used to obtain a biotite concentrate (no. 7) and a whole-rock sample (no. 8). From a sample of undeformed tonalite (Loc. 27.2), a chip was taken for wholerock analysis (no. 9), while a biotite concentrate (no. 10) was prepared from the rest of this sample. From all whole-rock samples, the major element composition as well as the $\mathrm{Rb}$ and $\mathrm{Sr}$ contents were determined.

To separate biotite from the ultramylonite 
(sample no. 7), the sample was ground to pass through a $60 \mu \mathrm{m}$ sieve. The fine dust was removed by washing and sieving, leaving a $20-$ $60 \mu \mathrm{m}$ fraction. This was processed in a LOCseparator (IJlst, 1973) resulting in an impure biotite concentrate no. 7a, consisting of polycrystalline grains of biotite with minor quartz and feldspar attached. The fine $(<20 \mu \mathrm{m})$ fraction was also processed, producing an optically pure biotite concentrate no. $7 \mathrm{~b}$. Both fractions were used for analysis.

The biotite of the tonalite was concentrated from a $125-250 \mu \mathrm{m}$ sieve fraction with the LOCseparator and a Faul table. $\mathrm{Rb}$ and $\mathrm{Sr}$ contents and $\mathrm{Rb} / \mathrm{Sr}$ ratios of the whole-rock samples were measured on pressed-powder pellets and major element composition on pearls by X-ray fluorescence spectrometry, using a Philips PW 1450/ AHP automatic spectrometer, with matrix corrections according Verdurmen (1977). The wholerock $\mathrm{Sr}$ isotope analyses were measured directly on unspiked $\mathrm{Sr}$. $\mathrm{Rb}$ and $\mathrm{Sr}$ contents of the biotite concentrates were analyzed by isotope dilution. All Sr analyses were performed on a Finnigan Mat 261 mass spectrometer, all Rb analyses on a Teledyne mass spectrometer. Analytical errors were estimated at $0.5 \%$ for XRF spectrometric $\mathrm{Rb} / \mathrm{Sr}$ and isotope dilution data, $0.01 \%$ for ${ }^{87} \mathrm{Sr} /{ }^{86} \mathrm{Sr}$ of whole-rocks, $0.02 \%$ for ${ }^{87} \mathrm{Sr} /{ }^{86} \mathrm{Sr}$ of minerals (Verdurmen, pers. comm., 1989). Best-fit lines through the data points were computed according to York (1967), with MSWD values after McIntyre et al (1966); errors quoted are on the $2 \sigma$ level. The age calculations are based upon the decay constant for ${ }^{87} \mathrm{Rb}$ of $1.42 \times$ $10^{-11} \mathrm{a}^{-1}$ (Steiger and Jäger 1977) and performed with the computer program DECAYSYS 3.2 written by P. Valbracht.

\section{Results and discussion}

\section{Analytical results}

The analytical results are listed in Tables I and II. Most of sample no. 3 was accidentally lost during milling; the results of the remaining no. 3 were greatly differing from the other samples and not considered further. The ultramylonite whole-rock data (Fig. 5) fit closely to an error-

Table 1 . Chemical analyses $(w t \%)$ of the tonalite and ultramylonite samples.

\begin{tabular}{|c|c|c|c|c|c|c|c|}
\hline type & $\begin{array}{c}\text { no. } \\
1 \\
\text { um }\end{array}$ & $\begin{array}{c}\text { no. } \\
2 \\
\text { um }\end{array}$ & $\begin{array}{c}\text { no. } \\
4 \\
\text { um }\end{array}$ & $\begin{array}{c}\text { no. } \\
5 \\
\text { um }\end{array}$ & $\begin{array}{c}\text { no. } \\
6 \\
\text { um }\end{array}$ & $\begin{array}{c}\text { no. } \\
8 \\
\text { um }\end{array}$ & $\begin{array}{c}\text { no. } \\
9 \\
\text { ton }\end{array}$ \\
\hline $\mathrm{SiO}_{2}$ & 67.19 & 67.29 & 68.63 & 62.87 & 61.58 & 65.78 & 67.31 \\
\hline $\mathrm{Al}_{2} \mathrm{O}_{3}$ & 14.57 & 14.00 & 13.66 & 16.15 & 16.51 & 14.60 & 16.19 \\
\hline $\mathrm{TiO}_{2}$ & .714 & .653 & .661 & .713 & .761 & .678 & .631 \\
\hline $\mathrm{Fe}_{2} \mathrm{O}_{3}$ & 5.88 & 5.63 & 5.20 & 6.56 & 6.81 & 5.90 & 4.18 \\
\hline $\mathrm{MgO}$ & 2.20 & 2.09 & 1.90 & 2.45 & 2.55 & 2.18 & 2.15 \\
\hline $\mathrm{MnO}$ & .059 & .052 & .060 & .072 & .072 & .060 & .048 \\
\hline $\mathrm{CaO}$ & 1.73 & 1.74 & 1.79 & 1.47 & 1.50 & 1.61 & 3.36 \\
\hline $\mathrm{NaO}$ & 2.88 & 2.74 & 2.89 & 2.64 & 2.68 & 2.74 & 4.54 \\
\hline $\mathrm{K}_{2} \mathrm{O}$ & 4.716 & 4.764 & 3.985 & 6.659 & 6.829 & 5.104 & 1.881 \\
\hline $\mathrm{BaO}$ & .131 & .126 & .099 & .180 & .186 & .133 & .037 \\
\hline $\mathrm{P}_{2} \mathrm{O}_{5}$ & .143 & .306 & .168 & .127 & .147 & .155 & .183 \\
\hline $\mathrm{LOI}^{2}$ & .00 & .30 & .40 & .50 & .40 & .30 & .30 \\
\hline Sum & 100.21 & 99.69 & 99.44 & 100.38 & 100.02 & 99.25 & 100.81 \\
\hline
\end{tabular}

1 ton = tonalite; um = ultramylonite

2 Loss on ignition

All analyses by XRF 


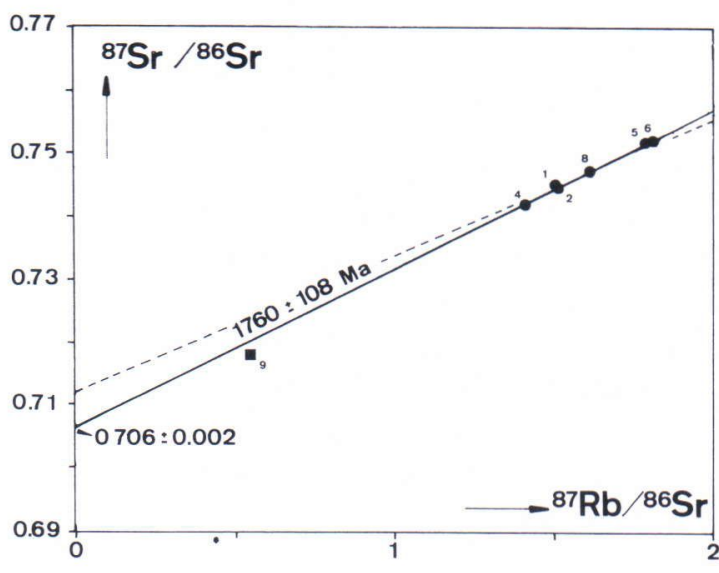

Fig. 5. Rb-Sr plot of the ultramylonite whole-rock data. Errors are smaller than symbol size. Dashed line is the biotite errorchron (biotite data points out of range). The labels refer to the sample codes in Table I. For explanation see text.

chron corresponding to an age of $1760 \pm 108 \mathrm{Ma}$ with an initial ${ }^{87} \mathrm{Sr} /{ }^{86} \mathrm{Sr}$ of $0.7066 \pm 0.0025$ (MSWD $=1.6)$. The large error is mainly due to the small spread in $\mathrm{Rb} / \mathrm{Sr}$ ratio. The biotite ages of the ultramylonite and tonalite are respectively $1533 \pm 23 \mathrm{Ma}(\mathrm{MSWD}=2.7$, using both biotite concentrates and no. 8) and $1644 \pm 16$ $\mathrm{Ma}$, with initials of $0.7120 \pm 0.0009$ and 0.7050 \pm 0.0002 .

\section{Interpretation of ages}

The biotite of the tonalite (loc. 27.2) is virtually not deformed nor recrystallized, so its age is unlikely to have been influenced by the mylonitization (see also the reference to Majoor (1988) below). The age of $1644 \pm 16 \mathrm{Ma}$ is consequently interpreted as a cooling age i.e. the time that the rock went through the blocking temperature for the $\mathrm{Rb}$-Sr isotope system in biotite, 300 $\pm 50^{\circ} \mathrm{C}$ (Jäger et al 1967). The biotite age of the ultramylonite must then represent an age reset by the mylonitization since the sample site of the tonalite is located close enough to the ultramylonite locality to rule out regional temperature differences. Because the biotite in the ultra-
Table 2. Rb and $\mathrm{Sr}$ contents and isotopical composition of whole-rock samples and biotite concentrates.

\begin{tabular}{lcccrc}
\hline Sampe & type ${ }^{1}$ & $\begin{array}{c}\mathrm{Rb} \\
(\mathrm{ppm})\end{array}$ & $\begin{array}{c}\mathrm{Sr} \\
(\mathrm{ppm})\end{array}$ & ${ }^{87} \mathrm{Rb} /{ }^{86} \mathrm{Sr}$ & ${ }^{87} \mathrm{Sr} /{ }^{86} \mathrm{Sr}$ \\
\hline no. 1 & um & 172 & 333 & 1.5031 & 0.745039 \\
no. 2 & um & 166 & 319 & 1.5113 & 0.744762 \\
no. 4 & um & 150 & 309 & 1.4099 & 0.742062 \\
no. 5 & um & 213 & 346 & 1.7891 & 0.751941 \\
no. 6 & um & 218 & 351 & 1.8057 & 0.752106 \\
no. 7a & um & 325 & 147 & 6.4875 & 0.855700 \\
no. $7 \mathrm{~b}^{2}$ & um & 424 & 114 & 11.0266 & 0.953419 \\
no. 8 & um & 179 & 323 & 1.6102 & 0.747180 \\
no. 9 & ton & 123 & 649 & 0.5473 & 0.717962 \\
no. $10^{2}$ & ton & 765 & 16 & 200.2874 & 5.447160 \\
\hline
\end{tabular}

1 ton = tonalite; um = ultramylonite

2 biotite concentrate

$\mathrm{Rb}$ and $\mathrm{Sr}$ contents of biotite concentrates by isotope dilution, all others by XFR

mylonite was completely broken down and recrystallized from its original $0.1-5 \mathrm{~mm}$ grain size in the tonalite to $\pm 5 \mu \mathrm{m}$, it is assumed that the biotite isotope system was completely reset. This is consistent with results of Etheridge and Cooper (1981). Majoor (1988) found Alpine ages for newly formed white mica in a shear zone, while the relic mica porphyroclasts have retained their original Variscan $\mathrm{Rb}-\mathrm{Sr}$ age. It is therefore concluded that the age of $1533 \pm 23 \mathrm{Ma}$ represents closure of the $\mathrm{Rb}-\mathrm{Sr}$ isotope system in biotite for the homogenizating process during mylonitization. This age is in agreement with the previous conclusion of field- and microtextural evidence that $D_{3}$ must have acted at least after $1641 \pm 13$ $\mathrm{Ma}$, the $\mathrm{U}-\mathrm{Pb}$ zircon age of the Bodom granite (Vaasjoki 1977). It can not be completely ruled out, however, that the age difference represents a lower closure temperature for smaller grain sizes, although this would be more likely for KAr than for the Rb-Sr system.

The whole-rock age of the ultramylonite sample is more difficult to interpret. As stated in the introduction, mylonite samples can yield various ages depending on the scale on which whole-rock rehomogenization took place, and the scale of 
sampling. If the system was closed (no exotic fluids involved), sampling on a larger scale would approximately give the original whole-rock age, sampling on a smaller scale the later event. Disturbance of the system by fluids would cause mixing, yielding meaningless, sometimes even negative, ages (Etheridge and Cooper 1981). The slices in this study are on the scale of ultramylonitic banding and can be expected to be equal to or smaller than the size of rehomogenization. Ploegsma (1989) showed on samples of the Suomusjärvi tonalite that an early amphibolite-facies $\mathrm{CO} 2$ fluid inclusion population is overprinted by low- grade $\left( \pm 400^{\circ} \mathrm{C}, 1 \mathrm{~kb}\right) \mathrm{H}_{2} \mathrm{O}$ fluids which are directly related to a late stage of the $\mathrm{D}_{3}$ shear zones. Nevertheless, the whole-rock age is significantly higher than the biotite age. The geological setting of the tonalite clearly proves intrusion before the peak of metamorphism $( \pm 1880 \mathrm{Ma}$ (Hopgood et al 1983) to $1830 \mathrm{Ma}$, the age of the Hanko granite (Huhma 1986)) so that $1760 \pm 108 \mathrm{Ma}$ cannot represent the original tonalite Rb-Sr age. Wever (1984) found a RbSr whole-rock age of $1967 \pm 122$ Ma for a similar, but hardly $\mathrm{D}_{3}$ affected, tonalite in the granulite facies area. The close fit to an errorchron of the data from the different slices indicates that partial resetting of the whole-rock age on a millimeter scale is related to the mylonitization rather than to a resetting during the peak of metamorphism. Incorporation of the tonalite whole-rock point into an errorchron calculation (which would result in an age of $1917 \pm 35 \mathrm{Ma}$ ) is therefore not justified.

I realize that this interpretation (especcially the biotite age of the tonalite) is in contradiction with other studies from south Finland, which indicate or suggest that $1.64 \mathrm{Ga}$ old rapakivi granites and even $1.8 \mathrm{Ga}$ ol granites intruded close the surface (e.g, Vorma 1976, Hubbard and Branigan 1987). The present results are, however, supported by petrological and fluid-inclusion data from the West Uusimaa area by Hartel (1988) and Touret and Hartel (1990), which point to a slow cooling path down to andalusite facies conditions, fol- lowed by a near-isothermal uplift. Hence the structural, petrological and fluid-inclusion data from the West Uusimaa area are entirely compatible with the results and interpretations from the present pilot study. So far, I have no explanation for this apparent discrepancy, e.g. no indications were found for the existence of largescale crustal blocks of the right age, scale and movement direction.

\section{Conclusions}

Although based on a pilot study with a limited amount of data, the results above are internally consistent and they allow a tentative reconstruction of the late deformation in southwest Finland, which was a phase of folding, shear zone formation and faulting. The biotite age of the Suomusjärvi tonalite suggests that around 1644 $\pm 16 \mathrm{Ma}$ ago the region had already cooled down below the $\mathrm{Rb}$-Sr blocking temperature of biotite. Resetting of the biotite age in the ultramylonite suggests deformation until at least $1533 \pm 23 \mathrm{Ma}$ ago. This is consistent with expectations based on cutting of the $1641 \pm 13$ Ma old Bodom granite by the Porkkala-Mäntsälä shear zone which is very likely of the same generation as the Suomusjärvi shear zone.

The age of $\mathrm{D}_{3}$ shows that major plastic and brittle deformation took place in southwest Finland 200-300 Ma after the main events of the Svecofennian phase and probably during active uplift of the belt. This implies that $\mathrm{D}_{3}$ could be a continental scale impact of the Gothian orogeny which took place from $1.75-1.5 \mathrm{Ga}$ ago in the Southwest Scandinavian Domain (Gaál and Gorbatschev 1987). The shear zones deforming granitic complexes on the Åland islands (Hubbard and Branigan 1987, Branigan 1987) might be related to the ones described here.

Acknowledgements. I am very grateful to the people of the NWO lab for Isotope Geology: Prof. Dr. H.N.A. Priem, Dr. R.H. Verschure, Dr. P.A.M. Andriessen and Peter Valbracht 
suggested the thin slab method, Lodewijk Ijlst and Richard Smeets introduced me into isotope-laboratory techniques. Peter Valbracht kindly provided his computer program DECAYSYS. I thank Frank Beunk, José van Duin, Fons van den Kerkhof, Folkert Majoor, Harry Stel, Jasques Touret, Dr. R.H. Verschure, Lázló Westra, Dr. J.S. Daly, Dr. A. McCaig and Dr. H. Huhma for their critical review of earlier drafts and Laura Cobb for correcting the English. This work is part of my Ph.D. study, financed by NWO (formerly ZWO), the Netherlands Organization for Scientific Research (grant no. 751.353.015) and supervised by Dr. L. Westra and Prof. Dr. J.L.R. Touret.

\section{References}

Abbot, J.T., 1972. Rb-Sr study of isotopic redistribution in a Precambrian mylonite-bearing shear zone, northern Front Range, Colorado. Geological Society of America Bulletin, 83, 487-494.

Black, L.P., 1988. Isotopic resetting of $\mathrm{U}-\mathrm{Pb}$ zircon and $\mathrm{Rb}-\mathrm{Sr}$ and Sm-Nd whole-rock systems in Enderby Land, Antarctica: implications for the interpretation of isotopic data from polymetamorphic and multiple deformed terrains. Precambrian Research, 38, 355-365.

-, L.P., Bell, T.H., Rubenach, M.J., \& Withnall, I.W. 1979. Geochronology of discrete structural metamorphic events in a multiple deformed Precambrian terrain. Tectonophysics, 54, 103-137.

Bleeker, W., \& Westra, L., 1987. The evolution of the Mustio gneiss dome, Svecofennides of SW Finland. Precambrian Research, 36, 227-240.

Branigan, N.P., 1987. The role of shearing in the Proterozoic development of the Åland archipelago, S.W. Finland. Bulletin of the Geological Society of Finland, 59, 117128.

Claesson, S., 1980. A Rb-Sr isotope study of granitoids and related mylonites in the Tännås Gneiss Nappe, southern Swedish Caledonides. Geologiska Föreningens i Stockholm Förhandlingar, 102, 403-420.

Colley, H., \& Westra, L., 1987. The volcano-tectonic setting and mineralization of the early Proterozoic KemiöOrijärvi-Lohja belt, SW Finland. In: Pharao, T.C., Beckinsale, R.D. and Rickard, D. (Eds): Geochemistry and Mineralization of Proterozoic Volcanic Suites, Geological Society Special Publications, 33, 95-107.

Etheridge, M.A., \& Cooper, J.A., 1981. Rb/Sr isotopic and geochemical evolution of a recrystallized shear (mylonite) zone at Broken Hill. Contributions to Mineralogy and Petrology, 78, 74-84.

Gaál, G., 1982. Proterozoic tectonic evolution and late Svecokarelian plate deformation of the Central Baltic Shield. Geologische Rundschau, 71, 158-170.

-, \& Gorbatschev, R., 1987. An outline of the precambrian evolution of the Baltic shield. Precambrian Research, $35,15-52$.

Grant, J.A., 1986. The isocon diagram - a simple solution to Grensens's equation for metasomatic alteration. Economic Geology, 2, 47-65.

Hanmer, S., 1987. Textural map units in quartzo-feldspatic mylonitic rocks. Canadian Journal of Earth Sciences, 24, 2065-2073.

Hickman, M.H., \& Glassley, W.E., 1984. The role of metamorphic fluid transport in the $\mathrm{Rb}-\mathrm{Sr}$ isotopic resetting of shear zones: evidence from Nordre Strømfjord, West Greenland. Contributions to Mineralogy and Petrology, $87,265-281$.

Hopgood, A.M., Bowes, D.R., Kouvo, O., \& Halliday, A.N., 1983. U-Pb and $\mathrm{Rb}-\mathrm{Sr}$ isotopic study of polyphase deformed migmatites in the Svecokarelides, southern Finland. In: Atherton, M.P., and Gribble, C.D. (Eds), Migmatites, Melting and Metamorphism. Shiva Publishers Limited, Nantwitch, England, 80-92.

Hubbard, F., \& Branigan, N., 1987. Late Svecofennian magmatism and tectonism, Åland, southwest Finland. Precambrian Research, 35, 241-256.

Huhina, H., 1986. Sm-Nd, U-Pb and $\mathrm{Pb}-\mathrm{Pb}$ isotopic evidence for the origin of the Early Proterozoic Svecokarelian crust in Finland. Geological Survey Finland Bulletin, 337, $48 \mathrm{pp}$.

IJlst, L., 1973. A laboratory overflow-centrifuge for heavy liquid mineral separation. American Mineralogist, 58, 1088-1093.

Jäger, E., Niggli, E., \& Wenk, E., 1967. Rb-Sr Alterbestimmungen an Glimmern der Zentralalpen. Beitrage Geologischer Karte Schweiz, 134.

Krishna Sinha, A., Hewitt, D.A., \& Rimstidt, J.D., 1986. Fluid interaction and element mobility in the development of ultramylonites. Geology, 14, 883-886.

Majoor, F.J.M., 1988. A geochronological study of the axial zone of the central Pyrenees, with emphasis on Variscan events and Alpine resetting. $\mathrm{Ph}$. D. thesis, University of Utrecht, the Netherlands, Verhandelingen, 6, ZWO laboratorium voor Isotopen Geologie Amsterdam, $119 \mathrm{pp}$.

McIntyre, G.A., Brooks, W., Compston, W. \& Turek, A. 1966. The statistical assessment of $\mathrm{Rb}-\mathrm{Sr}$ isochrons. Journal of Geophysical Research, 71: 5459-5468.

Nurmi, P.A., \& Haapala, I., 1986. The Proterozoic granitoids of Finland: granite types, metallogeny and relation 
to crustal evolution. Bulletin Geological Survey Finland, 58, part 1, 203-233.

Parras, $K$., 1958. On the charnockites in the light of a highly metamorphic rock complex in southwestern Finland. Bulletin de la Commision Geologique de Finlande, 181, $137 \mathrm{pp}$.

Ploegsma, M., 1987. Shear zones in the West Uusimaa area, SW Finland: sense of shear, fabric development and relation with D3. Abstracts Hans Ramberg Conference on Geological Kinetics and Dynamics, Uppsala, Sweden.

-, 1989. Shear zones in The West Uusimaa area, SW Finland. Unpublished Ph.D. thesis, Vrije Universiteit, Amsterdam: $134 \mathrm{pp}$.

—, \& Westra, L., 1990. The Early Proterozoic Orijärvi Triangle (SW Finland): a key area on the tectonic evolution of the Svecofennides. Precambrian Research 47: 51-69.

Schreurs, J., 1985. The west Uusimaa low pressure thermal dome, SW Finland. Ph. D. thesis, Free University Amsterdam, $179 \mathrm{pp}$.

—, \& Westra, L., 1986. The thermotectonic evolution of a Proterozoic, low pressure, granulite dome, West Uusimaa, SW Finland. Contributions to Mineralogy and Petrology, 93, 236-250.

Sederholm, J.J., 1913. Weitere Mitteilungen über Bruchspalten mit besonderer Bezichtigung zur Geomorphologie von Fennoskandia. Bulletin de la Commision Geologique de Finlande, 37, 1-66.

Sibson, R.H., 1975. Generation of pseudotachylyte by ancient seismic faulting. Geophysical Journal of the Royal Astronomical Society, 43, 775-749.

Simonen, A., 1980. The Precambrian in Finland. Geological Survey Finland Bulletin, 304, 58 pp.

Steiger, R.H., \& Jäger, G., 1977. Subcommission on geochronology - convention on the use of decay constants on geo- and cosmochronology. Earth and Planetary Science Letters, 36, 359-362.

Touret, J.L.R. \& Hartel, T.H.D., 1990. Synmetamorphic flu- id inclusions in granulites. In: D. Vielzeuf and $\mathrm{Ph}$. Vidal (Eds.), Granulites and Crustal Evolution: 397-417.

Törnroos, R., 1982. Sphalerite geobarometry of some metamorphosed sulphide ore deposits in Finland. Bulletin of the Geological Survey of Finland, 323, $42 \mathrm{pp}$.

Tuominen, H.V., 1957. The structure of an Archean area: Orijärvi, Finland. Bulletin de la Commission Geologique de Finlande, 177, 32 pp.

Vaasjoki, M., 1977. Rapakivi granites and other postorogenic rocks in Finland: their age and the lead isotopic composition of certain associated galena mineralizations. Geological Survey of Finland Bulletin, 294, 64 pp.

Van den Kerkhof, A.M., 1984. Mylonites and pseudotachylytes from Orijärvi and W-Uusimaa. Internal Report, Vrije Universiteit, Amsterdam.

Verdurmen, E.A.Th., 1977. Accuracy of X-ray fluorescence spectrometric determination of $\mathrm{Rb}$ and $\mathrm{Sr}$ in rock samples. X-ray Spectrometry, 6, 117-122.

Vorma, A. 1976. On the petrochemistry of rapakivi granites with special reference to the Laitala massif, southwestern Finland. Bulletin of the Geological Survey of Finland, 285: $98 \mathrm{pp}$.

Westra, L., \& Schreurs, J., 1985. The West-Uusimaa complex, Finland: an early Proterozoic thermal dome. In: Tobi, A.C., and Touret, J. (Eds) The Deep Proterozoic Crust in the North Atlantic Provinces. NATO ASI Series, 158, 369-380, Reidel, Dordrecht, Nederland.

Wever, H.E., 1984. Rb-Sr whole-rock age determinations of Svecofennian metavolcanics and early to synorogenic tonalites in the West Uusimaa granulite region, SW Finland. Unpublished M.Sc. thesis, Free University, Amsterdam.

York, D., 1967. The best isochron. Earth and Planetary Science Letters, 2, 479-482.

Received May 25, 1990

Revision accepted October 8, 1990 